\title{
Spherical Swelling of Germ Tubes and Hyphae of Fusarium oxysporum by the Treatment with 5 -fluoroindole
}

\author{
Teruo Nonomura*, Hideyoshi Toyoda*, Hiroyuki TAnPo***, Yoshinori MatsudA ${ }^{\dagger}$, \\ Kazuhiko MatsudA**, Abdul Gafur*, Mitsue Dogo* and Seiji Ouchi*
}

Key words : Fusarium oxysporum f. sp. lycopersici, 5-fluoroindole, antifungal activity, spherical swelling.

In our attempts to develop effective chemical control agents for soil-borne phytopathogenic bacteria of tomato, we found that indole and its related compounds (3-indolepropionic acid and 3-indoleacrylic acid) were capable of inhibiting the multiplication of Pseudomonas solanacearum $^{3,48)}$, the pathogen causing the bacterial wilt of tomato, and have clarified the correlation between chemical structures of these compounds and their antibacterial activities ${ }^{5,6)}$. These compounds were examined for their antifungal spectra against a variety of tomato pathogens, Cladosporium fulvum, Botrytis cinerea, Erysiphe cichoracearum, Fusarium oxysporum f. sp. lycopersici, Rhizoctonia solani, Pythium aphanidermatum, Verticillium albo-atrum and Phytophthora infestans, and were shown to be effective only to E. cichoracearum. Recently, 5-fluoroindole (5-FI) was found to inhibit the growth of some soil-borne pathogens, such as $F$. oxysporum, $R$. solani and $P$. aphanidermatum. In the present study, we report the spherical swelling of germtubes and vegetative hyphae of $F$. oxysporum f. sp. lycopersici by the treatment with 5 -FI and discuss the antifungal activity of this compound.

Screening of antifungal compounds. Microconidia of $F$. oxysporum Schlechtendahl f. sp. lycopersici (Saccardo) Snyder et Hansen, race I (KFOL-01) were collected from 10-day-cultures of an agar-solidified Czapek medium ${ }^{7}$ and spread onto the same solid medium. After 4 days of incubation at $26^{\circ} \mathrm{C}$ in dark, the edge portion of mycelial colonies was clipped by a cork borer (4 $\mathrm{mm}$ in diameter) and transferred to a solid Czapek medium containing $100 \mu \mathrm{g} / \mathrm{ml}$ of test compounds. The test medium was prepared by dissolving the compounds in $1 \%$ methanol and mixing them with an equal volume of a melted $2 \times$ Czapek-agar medium. This concentration of organic solvent $(0.5 \%$ methanol) was shown to be non-toxic to the fungal growth in our preliminary work. The compounds used were purchased from Sigma Chemical Co., St. Louis, MO, USA. After 6 days of incubation, the antifungal activity of the compounds was determined by measuring the radial growth of mycelia from discs. In the present screening of the antifungal compounds, we examined 145 indole related compounds (data not shown) and eventually found that 5-FI strongly inhibited the mycelial growth of KFOL-01.

Assay for effect on germination, mycelial growth, and sporulation. The density of microconidia was adjusted to $10^{4}$ spores $/ \mathrm{ml}$ in sterilized distilled water, and the conidial suspension was mixed with 9 parts of a melted Czapek-agar medium and thinly spread onto a glass slide. After solidification at room temperature, the conidia-embedded agar plates (fungal plate, $15 \times 20 \times 1 \mathrm{~mm}$ ) were dipped into the test medium (liquid Czapek medium containing various concentrations of 5-FI) immediately or after some periods of incubation. Morphological change of the fungal structures was examined with an Olympus differential interference contrast Nomarski microscope. First we treated non-germinated microconidia of KFOL-01 with 5-FI and examined whether this compound could suppress the germination of the fungus. Figure 1 shows the germination rates of microconidia of KFOL-01 versus concentrations of the treated compound. The result indicated that 5 -FI suppressed the conidial germination as an increase of concentrations of the compounds treated and that the treatment with 5-FI caused the spherical swelling of tips of germ tubes. As shown in Fig. 2, some of the microconidia initiated germination and produced germ tubes (Fig. 2A), but the tubes were swollen to form the spherical bodies (Fig. 2B). These spherical bodies increased their sizes and reached the maximum (approximately $15 \mu \mathrm{m}$ in diameter) $6 \mathrm{hr}$ after the treatment. The rates of spherical body formation were closely dependent on the concentrations of 5-FI and conspicuously high in microconidia treated with more than $25 \mu \mathrm{g} / \mathrm{ml}$ of 5-FI (Fig. 1). Either the elongation of germ tubes or the development of vegetative hyphae from the spherical

* Laboratory of Plant Pathology and **Laboratory of Pesticide Chemistry, Faculty of Agriculture, Kinki University, 3327-204 Nakamachi, Nara 631, Japan＼cjkstart近畿大学農学部

*** Hayashi Chemical Industry Co., Ltd., Minami-ku, Kyoto 601, Japan＼cjkstart林化学工業株式会社技術部

† Institute for Comprehensive Agricultural Science, Kinki University, 3327-204 Nakamachi, Nara 631, Japan 近畿大学 農学総合研究所 


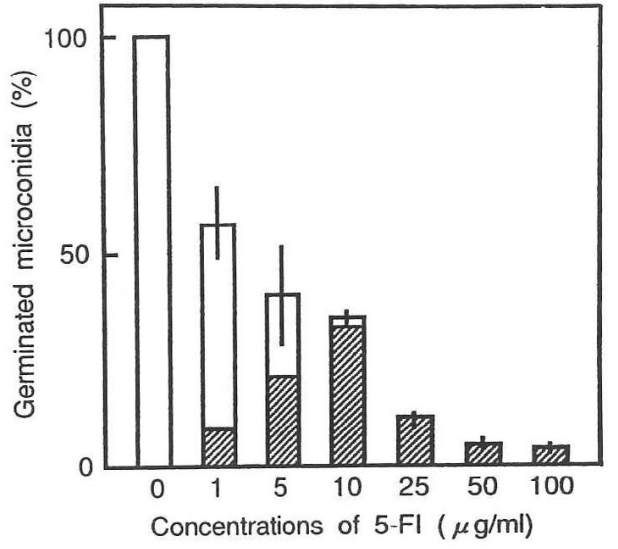

Fig. 1. Germination of microconidia of $F$. oxysporum $\mathrm{f}$. sp. lycopersici treated with 5 -fluoroindole (5-FI). Microconidia were embedded in an agarsolidified medium and dipped into a test solution containing various concentrations of 5-FI for 15 $\mathrm{hr}$. The rates of germination (open column) were expressed relative to the rate $(67.5 \pm 3.9 \%)$ of non-treated control. The shaded column represents the microconidia which formed spherical bodies on germ tubes. Data were given as means of five replications.
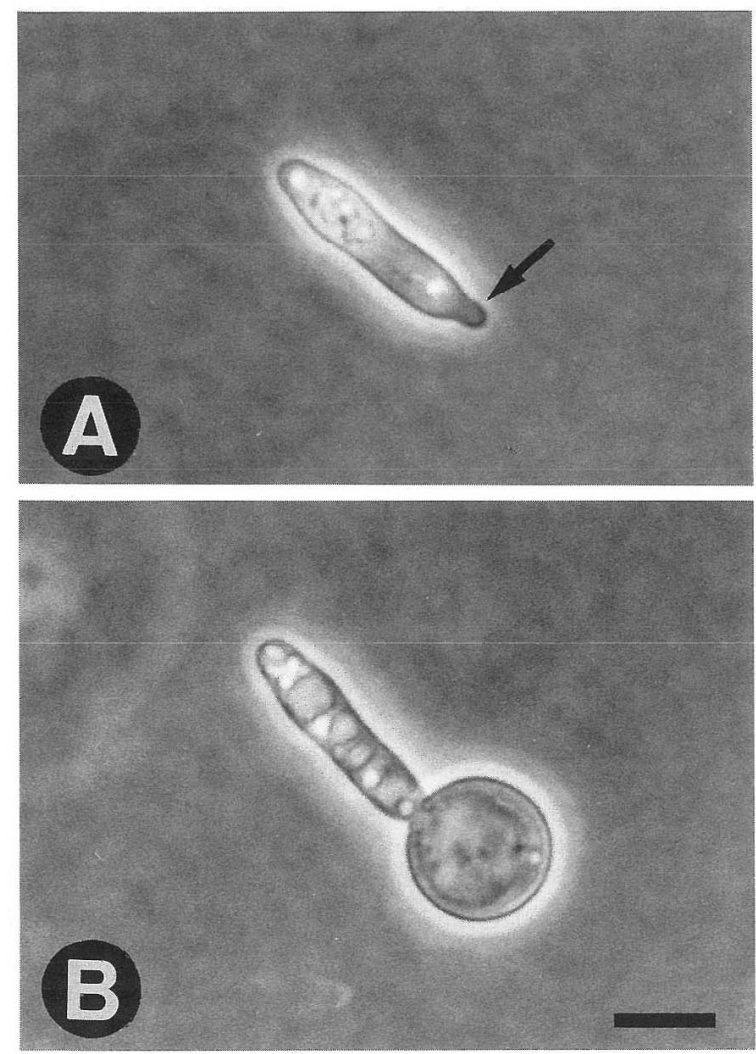

Fig. 2. Spherical swelling of germ-tube of microconidium of $F$. oxysporum f. sp. lycopersici by the treatment with 5-fluoroindole $(50 \mu \mathrm{g} / \mathrm{ml})$. The germ tube (arrow in A) swelled spherically and the spherical body reached the maximum diameter $6 \mathrm{hr}$ after the treatment (B). Bar represents $10 \mu \mathrm{m}$.
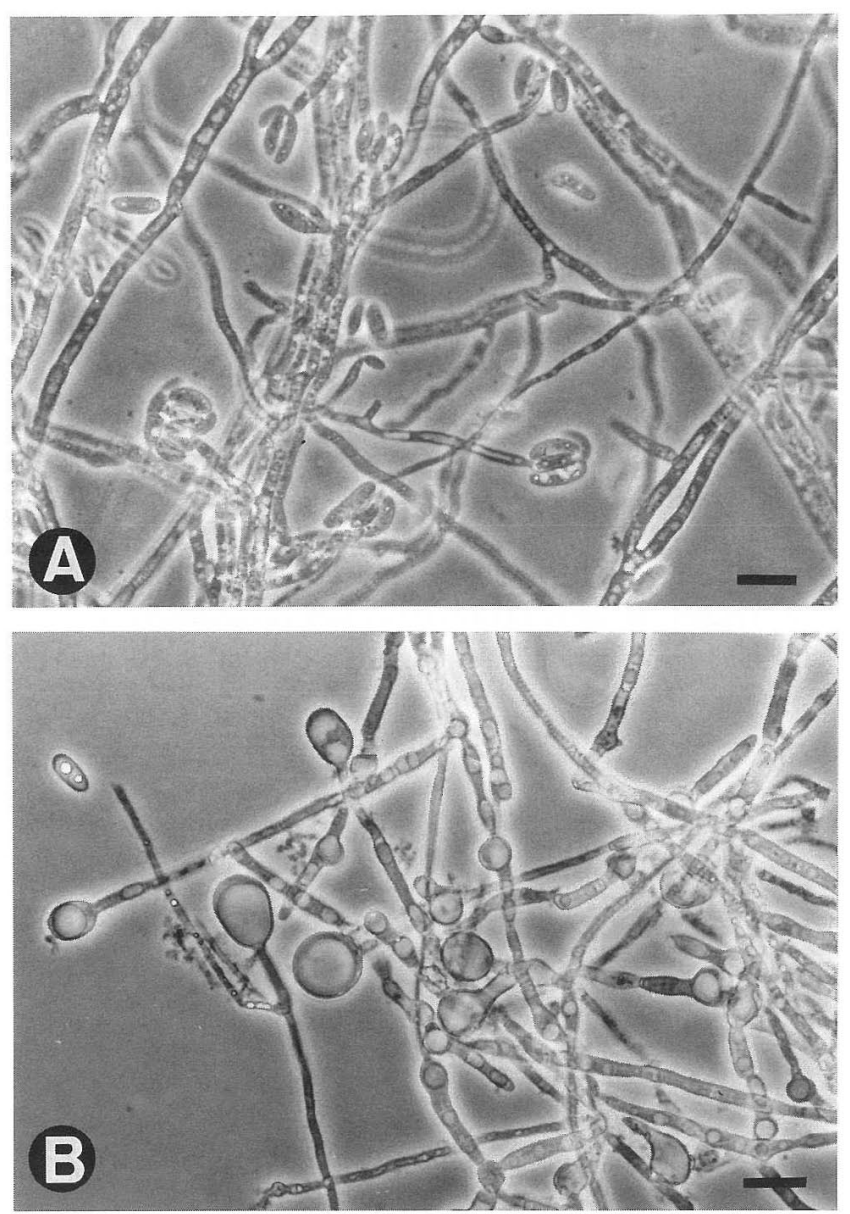

Fig. 3. Suppression of conidial formation of $F$. oxysporum f. sp. lycopersici by the treatment with 5-fluoroindole. The fungal plates were incubated for $72 \mathrm{hr}$ and treated with $50 \mu \mathrm{g} / \mathrm{ml}$ of 5 -fluoroindole. Vigorous formation of microconidia was observed in non-treated control (A). Note that the conidial formation was completely inhibited by the formation of spherical bodies in the pathogen (B) treated with 5 -fluoroindole. Bar represents $20 \mu \mathrm{m}$.

bodies was not observed in these microconidia.

The subsequent treatment with 5-FI was conducted using microconidia which had preliminarily cultured for various periods of times. Figure $3 \mathrm{~A}$ shows the elongated vegetative hyphae forming the microconidia at the numerous sites in non-treated control. In the 5-FItreated pathogen, however, the formation of conidia was completely inhibited and spherical bodies were formed at the tips and lateral sites of vegetative hyphae (Fig. 3B).

In order to clarify the correlation of biological activity of 5-FI with its chemical structure, we examined the effects of some substituents of 5-FI on the hyphal swelling and inhibition of mycelial growth of KFOL-01. As a result, the data indicated that the swelling was not induced either when fluorine of 5-FI was substituted by other atoms or radicals or when fluorine was transferred to other carbons of indole structure, although these 
Table 1. Effects of indole derivatives on the formation of spherical bodies (SB) and the mycelial growth of $F$. oxysporum f. sp. lycopersici, race I.

\begin{tabular}{|c|c|c|c|c|c|c|c|}
\hline \multirow{2}{*}{ Compounds } & \multirow{2}{*}{$\begin{array}{c}\text { Formation } \\
\text { of } \mathrm{SB}^{\mathrm{a})}\end{array}$} & \multicolumn{6}{|c|}{ Rate $(\%)$ of mycelial growth ${ }^{\mathrm{b})}$} \\
\hline & & 1 & 5 & 10 & 25 & 50 & $100^{c)}$ \\
\hline 5-fluoroindole & + & 100 & 86.1 & 78.8 & 36.1 & 0 & 0 \\
\hline 5-bromoindole & - & 100 & 96.9 & 75.0 & 34.4 & 0 & 0 \\
\hline 5-chloroindole & - & 97.1 & 92.1 & 84.2 & 34.2 & 18.4 & 0 \\
\hline 5-hydroxyindole & - & 89.4 & 89.4 & 97.0 & 97.0 & 90.9 & 83.3 \\
\hline 5-methylindole & - & 92.4 & 89.4 & 80.8 & 65.2 & 25.8 & 0 \\
\hline 5-cyanoindole & - & 84.8 & 87.9 & 87.9 & 83.3 & 77.3 & 42.4 \\
\hline indole-5-carboxylic acid & - & 87.9 & 89.4 & 89.4 & 92.4 & 89.4 & 89.4 \\
\hline 4-fluoroindole & - & 100 & 100 & 100 & 87.5 & 0 & 0 \\
\hline 6-fluoroindole & - & 100 & 100 & 100 & 97.5 & 80.0 & 19.2 \\
\hline indole & - & 100 & 100 & 100 & 100 & 100 & 70.8 \\
\hline
\end{tabular}

a) Treatment with $100 \mu \mathrm{g} / \mathrm{ml}$ of test compounds.

b) The growth rates were expressed relative to the rate of non-treated control. The data were given as means of five replications.

c) Concentrations $(\mu \mathrm{g} / \mathrm{ml})$ of test compounds.
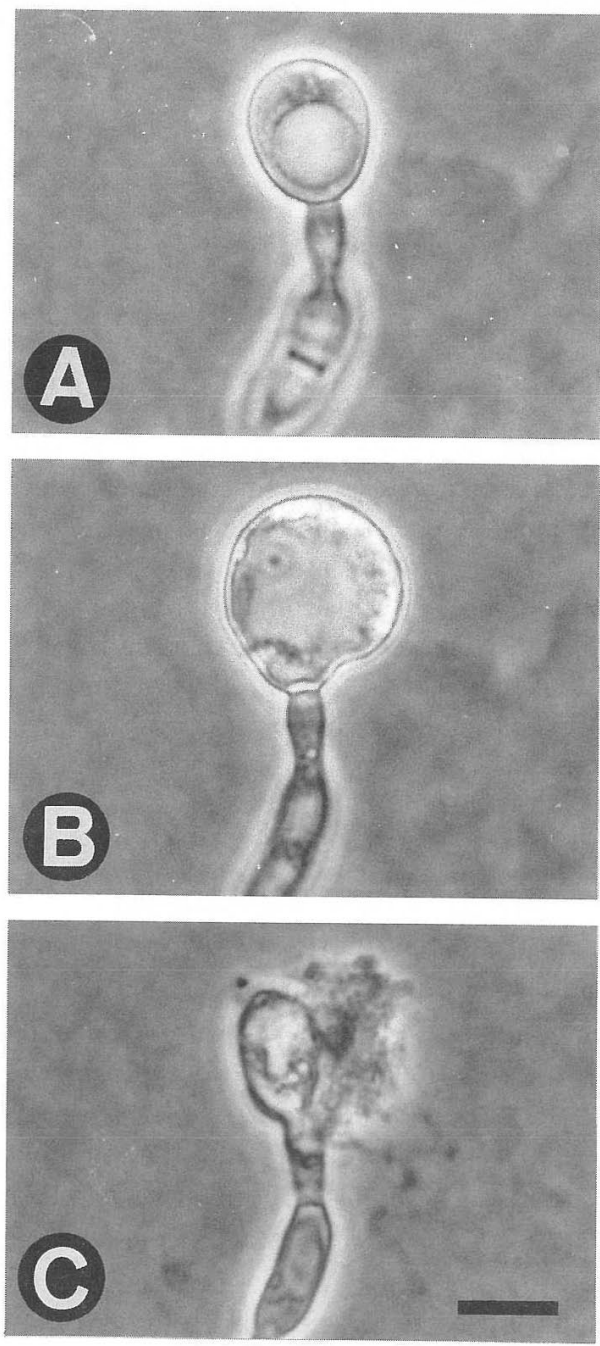

Fig. 4. Lysis of spherical body of germ tube of F. oxysporum $\mathrm{f}$. sp. lycopersici by osmotic pressure. The spherical bodies were induced in the germ tubes of microconidia under the same condition as in Fig. 2 and subjected to running water. Photographs of spherical structure was continuously taken 4 (A), 8 (B), and $12 \mathrm{hr}(\mathrm{C})$ after the treatment of osmotic shock. Bar represents $10 \mu \mathrm{m}$.

substituted compounds exhibited the inhibitory effect on the mycelial growth, depending on their concentrations (Table 1). These results indicate that the spherical swelling of hyphal tips could be specifically induced by the treatment with 5-FI, and the inhibition mechanism of this compound seems to be different from an inhibitory activity of other substituted compounds.

Test for osmotic sensitivity of spherical bodies. The fungal plate was placed on a glass slide, surrounded by a filter paper frame (5 mm wide) and sealed by a 
cover glass. Distilled water was supplied to the fungal plate by continuously dropping water onto the paper frame with a glass capillary and flowed water was blotted with a dried filter paper at the other side. The lysis of the spherical bodies was observed under microscopy under the continuous flow of running water (Fig. 4). In addition, the osmotic stability of the bodies was examined by dipping the fungal plate in an aqueous solution containing various concentrations of an osmotic stabilizer (between 0.1 and $1.1 \mathrm{M}$ mannitol) and the number of microconidia which maintained the spherical bodies was counted under microscopy. The result indicated that the spherical bodies were stably maintained by the addition of $0.7 \mathrm{M}$ mannitol, suggesting that the spherical body induced by 5-FI was a protoplast-like structure sensitive to osmotic shock. Although the biological function of 5-FI in $F$. oxysporum has not been obvious, some workers have reported that the tryptophan biosynthetic pathway of homobasidiomycete, Coprinus cinereus $^{9)}$ and the ectomycorrhizal basidiomycete Hebeloma cylindrosporum ${ }^{21}$ was feedback-inhibited by 5-fluorotryptophan intracellularly converted from 5-FI. Bhattiprolu et al. ${ }^{1}{ }^{1}$ conferred the resistance to 5 -FI on C. bilanatus by integrating the mutant anthranilate synthetase gene $\left(\operatorname{trp} 3^{\text {iar }}\right)$ from $C$. cinereus. The genetic complementation test by these mutant genes is underway in this fungus.

\section{Literature cited}

1. Bhattiprolu, G.R., Challen, M.P. and Elliott, T.J. (1993). Transformation of the homobasidiomycete Coprinus bilanatus to 5-fluoroindole resistance using a mutant trp3 gene from Coprinus cinereus. Mycol. Res. 97 : 12811286.

2. Durand, N., Debaud, J.C., Casselton, L.A. and Gay, G. (1992). Isolation and preliminary characterization of 5 -fluoroindole-resistant and IAA-overproducer mutants of the ectomycorrhizal fungus Hebeloma cylindrosporum Romagnesi. New Phytol. 121 : 545-553.

3. Kakutani, K., Toyoda, H., Matsuda, K., Nishida, T., Dogo, M., Saka, H., Hamada, M. and Ouchi, S. (1992). Antibacterial activities of indole and its related compounds against Pseudomonas solanacearum (III). In vivo assay for antibacterial activity of indole derivatives using detached tomato leaves and genetically marked pathogen. Ann. Phytopathol. Soc. Jpn. 58 : 784-788.

4. Matsuda, K., Toyoda, H., Kakutani, K., Hamada, M. and Ouchi, S. (1990). Antibacterial activities of indole against Pseudomonas solanacearum (I). Indole as an antibacterial substance against Pseudomonas solanacer m. Agric. Biol. Chem. $54:$ 3039-3040.

5. M .rsuda, K., Toyoda, H., Yokoyama, K., Wakita, K., Nishio, H., Nishida, T., Dogo, M., Kakutani, K., Hamada, M. and Ouchi, S. (1993). Growth inhibition of Pseudomonas solanacearum by substituted 3-indolepropionic acids and related compounds. Biosci. Biotech. Biochem. 57 : 1766-1767.

6. Matsuda, K., Toyoda, H., Nishida, T., Nishio, H., Dogo, M., Kakutani, K., Komai, K. and Ouchi, S. (1994). Antibacterial activity of indole and its related compounds against Pseudomonas solanacearum (V). Identification of a major metabolite of antibacterial 3indolepropionic acid in tomato leaves. Ann. Phytopathol. Soc. Jpn. 60 : 233-235.

7. Toyoda, H., Hashimoto, H., Utsumi, R., Kobayashi, H. and Ouchi, S. (1988). Detoxification of fusaric acid by a fusaric acid-resistant mutant of Pseudomonas solanacearum and its application to biological control of Fusarium wilt of tomato. Phytopathology 78 : 1307-1311.

8. Toyoda, H., Matsuda, K., Dogo, M., Kakutani, K., Akaza, K., Yamashita, S., Imanishi, Y., Matsuda, Y., Hamada, M. and Ouchi, S. (1991). Antibacterial activities of indole against Pseudomonas solanacearum (II). Inhibitory effect of indole derivatives on bacterial growth. Ann. Phytopathol. Soc. Jpn. 57 : 716-719.

9. Veal, D. and Casselton, L.A. (1985). Regulation of tryptophan metabolism in Coprinus cinereus: Isolation and characterization of mutants resistant to 5fluoroindole. Arch. Microbiol. 142 : 157-163.

\section{和 文 摘 要}

野々村照雄・豊田秀吉・反保宏行・松田克礼・松田一彦・Abdul GAFUR・道後充恵・大内成志：5-fluoroindole 処理によるトマト 萎ちょう病菌の発芽管および菌系先端の球状化

トマト萎ちょう病菌に対するインドール類縁化合物の増殖抑 制効果を検討したところ, 5 -fluoroindole (5-FI) が顕著な抑制効 果を示したので，この物質の作用についてさらに検討を加えた。 その結果，5-FI を未発芽小型分生胞子に処理した場合には，50 $\mu \mathrm{g} / \mathrm{ml}$ の濃度でほぼ完全に発芽を抑制し，わずかに発芽したも のでも, 発芽管の突起が形成された時点で球形に膨潤し, 以後の 伸長を停止した。また，あらかじめ培養して発芽管もしくは菌系 を伸長させた分生胞子に 5 -FI を処理した場合にも，それらの先 端部が球形に膨潤し, それ以後の伸長や胞子形成を抑制した。さ らに, 上記の球状構造体は浸透圧処理に感受性であることから, プロトプラスト様の構造であるものと推定された。

(Received October 23, 1995; Accepted March 27, 1996) 